\title{
Division of labor in transport and the influence of the public sector
}

\section{Josef KUBÍK ${ }^{1}$, Robert ZU゚VALA ${ }^{2}$}

\begin{abstract}
Urban mobility of persons is an important social phenomenon. It represents effected movement of people from one settlement to another, for reasons of performing purposeful and intentional activities related to work, education, shopping, procurement of services and number of others. Nowadays, mobility of persons poses serious environmental effects caused by a particularly extensive use of personal car traffic for transport of persons on their trips. The solution to this problem is one of the key elements in plans for improvement of sustainability of local development. Public administration pays consistently high attention to mobility of persons and by its decisions it fundamentally affects the quality of life of urban population. The basic trend is represented by the preference of environmentally friendly modes of transport. That is walking, cycling and mass public transport.

The indicator used for tracking of the use of the means of transport in urban mobility is the transport division of labor, the so-called modal split. This characteristic refers to the percentage of the various types of transport on the total number of trips performed by persons in a particular settlement in the course of one day, usually one working day.

The article examines the transport division of labor in Prague and in twelve regional capitals in the Czech Republic.

The work is conducted in two steps. The first step, the primary data is compiled into tables according to which of the defined modes of transport are used by people for travel to work and school in the regional capitals in the Czech Republic. The second step addresses the issue of consistence in the division of labor in transport across the tested set of cities. This hypothesis is assessed by a consistency test (chi-square test). The taken hypothesis was not confirmed and, therefore we examined the strength of the relationship between the observed and calculated frequencies of use of the various means of transport. The testing is carried out using adjusted residual values. For clearer representation and interpretation, the obtained results are transferred to the graphical form of a sign schema.
\end{abstract}

Keywords: public sector, modal split, population mobility, transport, inbound travel, statistical analysis.

JEL: O21, R41, R48

DOI: $10.24818 / \mathrm{amp} / 2018.30-01$

${ }^{1}$ Associate Professor, Ph.D., Engineer; Tomas Bata University in Zlín; Zlín; Czech
Republic; e-mail: kubik@ utb.cz
2 Magister; Transport Research Centre; Brno; Czech Republic; e-mail: r.zuvala@ seznam.cz 


\section{Introduction}

Residents of all types and sizes of municipalities have a need to exercise various activities during the day. Some of them can be conducted directly at residence, other need travel. The reasons why people change their place of normal or immediate residence is travelling to work, to educational institutions, to public offices, for services or shopping, but also commuting for access to culture, sports and other social activities (Bánociová \& Martinková, 2017; Poliak et al., 2017). The last trip on each day is then returning to the place of residence. The inhabitants of the city must be mobile, able to respond rapidly and effectively to the need to change their location within the city area. This is dependent on personal means, but also on the extent, availability, structure and service level of transport systems and on the organization of local transport.

Our own data and the calculations of the average number of trips made by a single citizen on a normal working day indicate between 2.8 and 3.0 trips. This figure is consistent with data published in foreign and domestic sources. The work of Becker, Gerike \& Winter (2008) notes that according to the opinion polls carried out in German cities in the years 1972 - 2003 people made three trips per standard working day on average. In the Czech Republic (CR), for instance, a report on mobility and local passengers transport (Mobility and local passengers transport, 2013) reported that, in 2013, a citizen of the city of Hradec Kralove made 12 trips per week (Monday - Sunday) on average, which is the equivalent of 1.7 per day. The report says that in 2009 the number was 2.2 per day. One source (Satisfaction of citizens with the local community, 2015) states that in the city of Jihlava the number of trips per working day per person was 2.78 in 2011 and $3.11 \mathrm{n} 2015$. According to the (General strategic paper of transport for the city of Zlín from 2016), the number of trips per citizen per working day was 2.47 .

Insight into the distribution of the purpose of trips made on a normal working day are provided by data from two regional capitals in the Czech Republic. The document (Plan of sustainable urban mobility, 2017) states that in the territory of Liberec and Jablonec nad Nisou in 2017 the distribution of trips according to their purpose is as follows: work (22\%); school (10\%); shopping $(10 \%)$; culture $(10 \%)$, sport, recreation $(11 \%)$; return journey to the place of residence $(44 \%)$. In the case of Jihlava (Satisfaction of citizens with the local community, 2015) the data from 2015 are as follows: trips to work (20.1\%); to school (6.9 \%); shopping (15.7\%); to the doctors (5.1\%); culture, sports \& recreation (9\%); return trip to the place of residence $(43 \%)$.

Transport division of labour or modal split indicates the share of the individual means of transport on the total number of transport trips made by the population in a city territory in one day (usually a working day) and is expressed as a percentage.

In all European cities, the transport division of labour is characterised by a high share of individual car transport. This has a major impact on global and local air pollution, local pollution by dust, growing noise and vibration, traffic congestion and a growing number of accidents. The reported environmental 
parameters, are dramatic in many cases, especially in cities. Apart from the traffic, the means of transport at rest also impact the environment, that is parking cars in public areas,

According to sources (Statistical yearbook of the Czech Republic, 2015), the number of cars per 1,000 citizens in the Czech Republic in 1981 was 182, in 1990 already 233, in 2000 it was 362, in 2010428 and in 2015 already 486. The annual growth of car ownership by approximately $2 \%$ continues.

The growth of car ownership is also the main reason for the increasing share of car transport on transport division of labour. For example, in the regional capitals of the Czech Republic, in accordance with the results of the Census of population, apartments and houses in 2001, the proportion of car transport on the total number of trips to work and school was between 11 and $21 \%$. The national census in 2011 reported for the same cities the share of car transport on transport trips to work and school in the range from 28 to $39 \%$.

Under (TEMS - The EPOMM Modal Split Tool, 2015), the share of car transport on transport trips of persons in randomly selected European cities were: Graz $47 \%$ (2013), Salzburg $45 \%$ (2012), Bologna $35 \%$ (2007), Parma $75 \%$ (2010), Erfurt $39 \%$ (2008), Koblenz $58 \%$ (2005), Nuremberg $33 \%$ (2011), Groningen $30 \%$ (2008), Besancon $60 \%$ (2004).

The reported levels of transport division of labour across Czech and European cities with a high share of car transport and a low share of public transport are a result of the past long-term development based on sustained growth of car ownership and an insufficient support of sustainable means of transport.

The aim of our article is to assess conformity in transport division of labour between regional capitals in the Czech Republic. If the conformity is not proven, we will conduct quantification and evaluation of the differences in the use of various types of transport in the corresponding city related to the calculated standard.

In the article, we present the data source and specify the purpose of the trip for which the calculation of the transport division of labour is available. Subsequently, we are dealing with the definition of the methodology of our own empirical analysis. The following part contains a presentation and discussion of the results. In conclusion, we review the main findings and list possible directions of future research.

\section{Objective, methodology and assumptions of the analysis}

The aim of this article is as certain, whether the transport division of labour is or is not identical across regional capitals of the Czech Republic. In case of divergence, we intend to express the difference by determining the deviation of observed frequencies from the theoretical frequencies of use of the respective means of transport in the examined city.

The analysis of the accepted project is carried out on a unique data set generated by the national census, which took place at midnight from Friday 25 th to 
Saturday 26th March 2011. The uniqueness of the data set is based on the scope of the investigation, the used methodology and the record date of the national censuses. The availability of such data file is only once in a 10-year period.

The result of the countrywide census are also answers of respondents on the usual use of the means of transport by employees, pupils, students and apprentices in a single trip to work or school, broken down by the individual municipalities in the Czech Republic.

For the purposes of this article, we processed the originally collected data for the residents of the regional capitals travelling to work and school in the city and outside the city. From the assembled data we made the chart No. 2 showing persons travelling into work and school, by regional capital and of the means of transport used. The data on inbound travel to work and school by regional capitals and by the means of transport used was sourced from a publication of the Statistical Office (Inbound travel to work and school, 2011) and is presented in table No. 3.

The actual research is conducted in two scenarios, each of which has three alternatives. In the first scenario, we are working with the data set of persons travelling to work and school, the second scenario we use the data set for inbound and outbound travel of persons to work and school. The established alternatives differ in the number of cities included in the analysed set.

The analytical work of examining the adopted objective is carried out in two steps. First, we test the statistical independence. The so-called zero hypothesis assumes that observed transport division of labour is identical across the selected range of regional capitals. In case of its confirmation, the procedure is completed. Otherwise we will make a quantification of the differences in the use of various types of vehicles and evaluate their statistical significance. Thus, we get a quantitative overview of the transport division of labour level reached by each of the cities.

Such result material may also be used by authorities and bodies of the public administration in the design of the development plans of urban mobility, the acquired knowledge can be used in research of transport behaviour of urban population, etc.

\section{Methodological approach to the research subject of the article}

\subsection{The chi-square test}

We test the hypothesis $\mathrm{H}_{0}$, which is as follows: The distribution of the use of the means of transport on trips to work and school across a set of regional capitals in the Czech Republic, does not show any statistically significant difference.

The alternative hypothesis to the $\mathrm{H}_{0}$ hypothesis is the claim that the transport division of labour across the examined set of regional capitals shows a statistically significant difference.

In accordance with the zero hypothesis, during the testing we calculate theoretical values for each case from empirical input data. Subsequently we 
compare the empirical and theoretical frequencies and from their differences data we calculate the value of the criterion for Pearson's chi-square test. Then we compare the result with critical (table) value corresponding to $5 \%$ significance level. The tested hypothesis will be accepted only if the calculated value does not exceed the limit defining the critical range.

The explanatory capacity of the chi-square statistic lies only in the acceptance or rejection of the zero hypothesis of dependence or homogeneity of the data on the respective alpha level of significance.

If the tested hypothesis is rejected, that is if there is a statistically significant deviation in transport division of labour, the Cramer contingency coefficient is used to measure its intensity (the so-called Cramer's V). The scale of dependence ranges from 0 , which means independence, to 1 , which is strong dependence.

\subsection{Adjusted residues and sign chart}

In cases of refusal of the test hypothesis H0, i.e. the distribution of means of transport across the tested set of regional capitals is not identical, the results of the consistency test can be further specified through the method of adjusted residues. We determine the strength of the relationship between the observed and expected frequency.

The adjusted residue is based on the difference between the empirical (observed) and theoretical (expected) frequency. The differences are standardized through division by the standard deviation. The adjusted residues can be interpreted using a sign chart. Each value shall be replaced by the relevant sign. The type of the sign represents the direction and also the strength of the deviation:

a) The direction of deviation

- The empirical frequency does not significantly differ from the theoretical one. Type of sign o.

- The empirical frequency is higher compared with the theoretical one. Type of sign "+".

- The empirical frequency is lower compared with the theoretical one. Type of sign "-.".

b) Strength of the deviation

In each cell of the table, there can be up to three plus or minus signs, according to the statistical significance of the deviation. These properties correspond to quantile values of normalized normal distribution:

- The absolute value of the adjusted residue (from) $>=\mathbf{3 . 2 9}$ is replaced by +++ or --- for the selected significance level of $0.1 \%$.

- The absolute value of the adjusted residue (from) $>=\mathbf{2 . 5 8}$ is replaced by ++ or -- for the selected significance level of $1 \%$.

- The absolute value of the adjusted residue (from) $>=\mathbf{1 . 9 6}$ is replaced by + or - for the selected significance level of $5 \%$. 


\section{Assumptions of the analysis}

Fundamental input data for the analysed subject are listed in the table No. 1

Table 1. Number of inhabitants, territory, economically active and students, inbound and outbound travel to work and school

\begin{tabular}{|c|c|c|c|c|c|}
\hline City & Number of \\
inhabitants & $\begin{array}{c}\text { The } \\
\text { cadastral } \\
\text { area in } \\
\mathbf{k m}^{2}\end{array}$ & $\begin{array}{c}\text { The } \\
\text { economically } \\
\text { active, pupils, } \\
\text { students and } \\
\text { apprentices }\end{array}$ & $\begin{array}{c}\text { Outbound } \\
\text { travel to work } \\
\text { and school }\end{array}$ & $\begin{array}{c}\text { Inbound } \\
\text { travellers to } \\
\text { work and } \\
\text { school }\end{array}$ \\
\hline Prague & $1,268,796$ & 496 & 748,191 & 363,057 & 199,360 \\
\hline Brno & 385,913 & 230 & 226,074 & 114,315 & 100,049 \\
\hline Ostrava & 296,224 & 214 & 163,682 & 74,753 & 50,895 \\
\hline Plzen & 170,322 & 138 & 98,113 & 44,235 & 37,486 \\
\hline Olomouc & 101,003 & 103 & 60,587 & 31,951 & 33,040 \\
\hline Liberec & 102,754 & 106 & 59,647 & 25,439 & 14,880 \\
\hline České Budějovice & 93,715 & 56 & 55,879 & 24,290 & 29,699 \\
\hline Hradec Králové & 94,314 & 106 & 55,476 & 23,838 & 23,828 \\
\hline Ústí nad Labem & 93,000 & 94 & 50,505 & 20,275 & 13,668 \\
\hline Pardubice & 90,767 & 83 & 53,708 & 25,238 & 20,600 \\
\hline Zlín & 75,318 & 103 & 44,602 & 20,322 & 17,387 \\
\hline Jihlava & 50,075 & 88 & 29,403 & 12,992 & 15,064 \\
\hline Karlovy Vary & 46,839 & 59 & 26,132 & 9,708 & 8,673 \\
\hline
\end{tabular}

(Source: The census of population, apartments and houses 2011)

The data on the number of inhabitants, territory, economically active and students represent comprehensive data for the population of the Czech Republic from the central register. The data on inbound and outbound travel of persons to work or school represent the number of respondents who have reported typically used means of transport for one trip into work or school in the census questionnaire.

Table 2. Numbers of outbound travel of persons to work and school, by means of transport used

\begin{tabular}{|c|c|c|c|c|c|c|c|}
\hline City & Walking & Cycling & $\begin{array}{c}\text { Mass } \\
\text { public } \\
\text { transport }\end{array}$ & $\begin{array}{c}\text { Bus } \\
\text { public } \\
\text { transport }\end{array}$ & Train & $\begin{array}{c}\text { Car } \\
\text { transport }\end{array}$ & $\begin{array}{c}\text { Combined } \\
\text { transport }\end{array}$ \\
\hline Prague & 37,310 & 2,213 & 199,604 & 9,246 & 1,685 & 76,376 & 36,623 \\
\hline Brno & 14,810 & 1,131 & 54,754 & 2,899 & 597 & 28,651 & 11,473 \\
\hline Ostrava & 10,720 & 783 & 32,419 & 2,618 & 815 & 19,104 & 8,294 \\
\hline Plzen & 5,805 & 509 & 18,404 & 1,374 & 311 & 12,807 & 5,025 \\
\hline Olomouc & 6,823 & 1,343 & 9,347 & 1,519 & 676 & 8,038 & 4,205 \\
\hline
\end{tabular}


Division of labor in transport and the influence of the public sector

\begin{tabular}{|c|c|c|c|c|c|c|c|}
\hline City & Walking & Cycling & $\begin{array}{c}\text { Mass } \\
\text { public } \\
\text { transport }\end{array}$ & $\begin{array}{c}\text { Bus } \\
\text { public } \\
\text { transport }\end{array}$ & Train & $\begin{array}{c}\text { Car } \\
\text { transport }\end{array}$ & $\begin{array}{c}\text { Combined } \\
\text { transport }\end{array}$ \\
\hline Liberec & 4,976 & 204 & 7,952 & 1,333 & 166 & 8,104 & 2,704 \\
\hline $\begin{array}{c}\text { České } \\
\text { Budějovice }\end{array}$ & 4,639 & 2,046 & 6,112 & 1,211 & 284 & 6,607 & 3,391 \\
\hline Hradec Králové & 3,860 & 2,234 & 5,514 & 1,030 & 428 & 6,881 & 3,891 \\
\hline Ústí nad Labem & 3,116 & 107 & 7,052 & 846 & 510 & 6,214 & 2,430 \\
\hline Pardubice & 4,258 & 2,598 & 5,966 & 902 & 816 & 6,414 & 4,284 \\
\hline Zlín & 3,089 & 276 & 7,063 & 848 & 338 & 6,342 & 2,366 \\
\hline Jihlava & 3,213 & 214 & 3,465 & 670 & 134 & 4,020 & 1,276 \\
\hline Karlovy Vary & 1,846 & 98 & 2,417 & 762 & 132 & 3,381 & 1,072 \\
\hline
\end{tabular}

(Source: The census of population, apartments and houses 2011)

Table 2 compares the data on the means of transport used for a group of persons residing in the city and travelling to work or school in the city or to other municipalities or abroad. The share of people with a place of work or school directly in the city is between $65-92 \%$. Individual car transport is an indication of the persons travelling by car as a driver or passenger. In this composition, the share of car drivers on car transport through the mentioned cities is $83 \%$ to $91 \%$.

Table 3. Numbers of inbound travellers to work and school, by means of transport used

\begin{tabular}{|c|c|c|c|c|c|c|c|}
\hline City & Walking & Cycling & $\begin{array}{c}\text { Mass } \\
\text { public } \\
\text { transport }\end{array}$ & $\begin{array}{c}\text { Bus public } \\
\text { transport }\end{array}$ & Train & $\begin{array}{c}\text { Car } \\
\text { transport }\end{array}$ & $\begin{array}{c}\text { Combined } \\
\text { transport }\end{array}$ \\
\hline Prague & 3,805 & 410 & 35,561 & 16,333 & 13,244 & 65,404 & 64,603 \\
\hline Brno & 3,800 & 322 & 16,177 & 9,556 & 8,793 & 27,834 & 33,557 \\
\hline Ostrava & 887 & 212 & 5,790 & 5,734 & 3,385 & 20,840 & 14,047 \\
\hline Plzen & 775 & 159 & 3,783 & 3,904 & 3,226 & 15,257 & 10,382 \\
\hline Olomouc & 1,779 & 350 & 2,687 & 3,950 & 4,638 & 10,186 & 9,450 \\
\hline Liberec & 690 & 58 & 1,452 & 2,190 & 1,112 & 5,787 & 3,591 \\
\hline $\begin{array}{c}\text { České } \\
\text { Budějovice }\end{array}$ & 932 & 374 & 2,976 & 5,076 & 1,869 & 11,802 & 6,670 \\
\hline $\begin{array}{c}\text { Hradec } \\
\text { Králové }\end{array}$ & 942 & 364 & 1,316 & 2,564 & 2,591 & 9,536 & 6,515 \\
\hline $\begin{array}{c}\text { Ústí nad } \\
\text { Labem }\end{array}$ & 320 & 27 & 1,189 & 646 & 2,681 & 4,867 & 3,938 \\
\hline Pardubice & 738 & 464 & 1,302 & 2,383 & 2,261 & 8,087 & 5,365 \\
\hline Zlín & 450 & 80 & 1,520 & 4,623 & 927 & 6,350 & 3,437 \\
\hline Jihlava & 323 & 46 & 381 & 3,765 & 623 & 7,111 & 2,815 \\
\hline Karlovy Vary & 105 & 39 & 327 & 1,609 & 400 & 3,621 & 2,572 \\
\hline
\end{tabular}

(Source: Census of population, apartments and houses 2011) 
Table 3 shows the data about the means of transport used for the group of inbound travellers to work and school in the respective city.

\section{The results of the discussion}

The analysis of the transport division of labour is performed for two scenarios. Each of the scenarios has three alternatives. The first scenario represents the data on the transport division of labour for citizens travelling from city to work and school. The second scenario is a collection of data on the transport division of labour for inbound and outbound travel of persons to work and school within the city territory.

The alternatives of the transport division of labour analysis represent the following sets of cities:

a) Regional capitals and the country capital city of Prague

The set consists of Prague and twelve cities with seats of the regional governments.

b) All regional capitals except for Prague and Brno.

Prague and Brno showed a high share on the input data. $60 \%$ in the first scenario and $57 \%$ in the second one. The size of the two cities and their developed system of mass public transport significantly affects the calculated theoretical frequency of transport division of labour. In the alternative, the data for both cities are excluded from the examined data sets.

c) Regional capitals with population of 75 - 105 thousand inhabitants.

In the analysis includes data from the following cities: Olomouc, Liberec, České Budějovice, Hradec Kralove, Usti nad Labem, Pardubice and Zlín. These cities have comparable populations with similar public transport systems.

\subsection{Chi-square test}

We apply the consistency test (chi-square test) on the data of scenario 1 . We test the hypothesis $\mathrm{H}_{0}$, whether the transport division of labour of outbound travel of people to work and school is or is not the same throughout the Czech regional capitals by individual alternatives. The results of the test for the three alternatives are listed in the table No 4.

Table 4. Outbound travel of persons to work and school - Chi-square tests

\begin{tabular}{|c|c|c|c|c|c|c|c|c|c|}
\hline & \multicolumn{3}{|l|}{ Alternative A } & \multicolumn{4}{l|}{ Alternative B } & \multicolumn{2}{|c|}{ Alternative C } \\
\hline & Value & DF & $\begin{array}{c}\text { Asymp. } \\
\text { Sig. (2- } \\
\text { sided) }\end{array}$ & Value & DF & $\begin{array}{c}\text { Asymp. } \\
\text { Sig. (2- } \\
\text { sided) }\end{array}$ & Value & DF & $\begin{array}{c}\text { Asymp. } \\
\text { Sig. (2- } \\
\text { sided) }\end{array}$ \\
\hline $\begin{array}{c}\text { Pearson Chi- } \\
\text { Square }\end{array}$ & $71,335.7$ & 72 & 0.000 & $20,173.0$ & 48 & 0.000 & $8,397.4$ & 36 & 0.000 \\
\hline Likelihood Ratio & $59,146.3$ & 72 & 0.000 & 19030.5 & 48 & 0.000 & $9,178.3$ & 36 & 0.000 \\
\hline $\begin{array}{c}\text { Number of Valid } \\
\text { Cases }\end{array}$ & 789,789 & & & 290,109 & & & 171,176 & \\
\hline
\end{tabular}

(Source: The actual processing, 2018) 
In all three alternatives, the value of the test criteria of the Pearson chisquare with double-sided significance 0.000 above normative values. The $\mathrm{H}_{0}$ hypothesis postulating the same distribution of transport division of labour for outbound travel of persons to work and school across regional capitals is rejected for all three alternatives because of a statistically significant difference.

The value of Cramer's V in all alternatives tells us that the strength of the deviation shows a weak, i.e. independent relationship, but it is statistically significant ( $\mathrm{p}$-value $=0.000$ ). The strength of the relationship can be expected in the whole population of the Czech Republic.

We apply the consistency test (chi-square test) on the data of scenario 2 . We test the $\mathrm{H} 0$ hypothesis, whether the transport division of labour of inbound and outbound travel of persons to work and school is or is not the same throughout the Czech regional capitals in the individual alternatives. The results of the test for the three alternatives are listed in the table No 5.

Table 5. Inbound and outbound travel of persons to work and school Chi-square tests

\begin{tabular}{|c|c|c|c|c|c|c|c|c|c|}
\hline & \multicolumn{3}{|l|}{ Alternative A } & \multicolumn{4}{l|}{ Alternative B } & \multicolumn{3}{l|}{ Alternative C } \\
\hline & Value & $\begin{array}{r}\text { DF } \\
\text { Digmp. } \\
\text { Sig. (2- } \\
\text { sided) }\end{array}$ & Value & DF & $\begin{array}{c}\text { Asymp. } \\
\text { Sig. (2- } \\
\text { sided) }\end{array}$ & Value & DF & $\begin{array}{c}\text { Asymp. } \\
\text { Sig. (2- } \\
\text { sided) }\end{array}$ \\
\hline $\begin{array}{c}\text { Pearson Chi- } \\
\text { Square }\end{array}$ & $109,186.6$ & 72 & 0.000 & $29,881.6$ & 48 & 0.000 & $14,787.60$ & 36 & 0.000 \\
\hline Likelihood Ratio & $98,321.10$ & 72 & 0.000 & $28,459.6$ & 48 & 0.000 & $15,462.10$ & 36 & 0.000 \\
\hline $\begin{array}{c}\text { Number of Valid } \\
\text { Cases }\end{array}$ & $1,353,998$ & & & 531,368 & & & 324,108 & & \\
\hline
\end{tabular}

(Source: The actual processing, 2018)

In all three alternatives, the value of the test criteria of the Pearson chisquare with double-sided significance 0.000 above normative values. The hypothesis $\mathrm{H} 0$ about the same distribution of transport division of labour for inbound and outbound travel of persons to work and school across regional capitals are rejected for all three alternatives because of the existence of a statistically significant difference.

The value of Cramer's $V$ in all alternatives describes us that the strength of the deviation shows a weak, i.e. independent relationship, but it is statistically significant ( $\mathrm{p}$-value $=0.000$ ). The strength of the relationship can be expected in the whole population of the Czech Republic.

\subsection{Adjusted residues and sign chart}

The previous test in both scenarios and their alternatives proved that there are no identical transport division of labour distributions across any of the data sets of regional capitals. Therefore, we proceed to evaluation of the strength of the relationship between empirical and theoretical frequencies of use of the individual 
means of transport in each of the examined cities. Thus, we get the opportunity of a detailed insight into the structure of the dependence.

With regard to the magnitude of the evaluated data, we will henceforth focus on the alternative $\mathrm{C}$, that is on the group of six cities in both scenarios.

The transport division of labour is specified using the seven possible means of transport. Six of them include a single mode of transport and one is combined, meaning use of two or more modes of transport. According to the collected data, 9 to $17 \%$ of travellers reported that they use car as the primary mode of transport, in the data set including inbound and outbound travellers the share is between 5 and 9 $\%$. The rest include a combination of other means of transport. Regarding these relationships, we consider the combined transport as friendly to the environment.

In table No. 6 and 7 we include transport division of labour, the adjusted residues and their transformation into the sign chart for outbound travellers to work and school.

Table 6. Outbound travellers to work and school

(transport division of labour and adjusted residues)

\begin{tabular}{|c|c|c|c|c|c|c|c|c|}
\hline City & & Walking & Cycling & $\begin{array}{c}\text { Mass } \\
\text { public } \\
\text { transport }\end{array}$ & $\begin{array}{c}\text { Bus } \\
\text { public } \\
\text { transport }\end{array}$ & Train & $\begin{array}{c}\text { Car } \\
\text { transport }\end{array}$ & $\begin{array}{l}\text { Combined } \\
\text { transport }\end{array}$ \\
\hline \multirow[t]{2}{*}{ Olomouc } & $\begin{array}{l}\text { Share of } \\
\text { transport }\end{array}$ & $22 \%$ & $4 \%$ & $29 \%$ & $5 \%$ & $2 \%$ & $25 \%$ & $13 \%$ \\
\hline & $\begin{array}{c}\text { Adjusted } \\
\text { residual }\end{array}$ & 17.6 & -8.4 & 2.8 & 2.5 & 3.5 & -14.1 & -2.3 \\
\hline \multirow[t]{2}{*}{ Liberec } & $\begin{array}{l}\text { Share of } \\
\text { transport }\end{array}$ & $20 \%$ & $1 \%$ & $31 \%$ & $5 \%$ & $1 \%$ & $32 \%$ & $10 \%$ \\
\hline & $\begin{array}{c}\text { Adjusted } \\
\text { residual }\end{array}$ & 7.3 & -33.9 & 10.3 & 6.3 & -15.6 & 13.5 & -15.3 \\
\hline \multirow[t]{2}{*}{\begin{tabular}{|c|} 
České \\
Budějovice
\end{tabular}} & $\begin{array}{l}\text { Share of } \\
\text { transport }\end{array}$ & $19 \%$ & $8 \%$ & $25 \%$ & $5 \%$ & $1 \%$ & $28 \%$ & $14 \%$ \\
\hline & $\begin{array}{c}\text { Adjusted } \\
\text { residual }\end{array}$ & 5 & 25 & -12.8 & 4.0 & -8.8 & -4.3 & 1.9 \\
\hline \multirow[t]{2}{*}{$\begin{array}{l}\text { Hradec } \\
\text { Králové }\end{array}$} & $\begin{array}{l}\text { Share of } \\
\text { transport }\end{array}$ & $16 \%$ & $9 \%$ & $23 \%$ & $4 \%$ & $2 \%$ & $30 \%$ & $16 \%$ \\
\hline & $\begin{array}{c}\text { Adjusted } \\
\text { residual }\end{array}$ & -7.6 & 31.9 & -20.1 & -1.3 & -1 & 1.9 & 13.3 \\
\hline \multirow[t]{2}{*}{$\begin{array}{l}\text { Ústí nad } \\
\text { Labem }\end{array}$} & $\begin{array}{l}\text { Share of } \\
\text { transport }\end{array}$ & $15 \%$ & $1 \%$ & $35 \%$ & $4 \%$ & $3 \%$ & $30 \%$ & $12 \%$ \\
\hline & $\begin{array}{c}\text { Adjusted } \\
\text { residual }\end{array}$ & -10.3 & -31.7 & 20.7 & -2.30 & 7.1 & 7.6 & -6.8 \\
\hline \multirow[t]{2}{*}{ Pardubice } & $\begin{array}{l}\text { Share of } \\
\text { transport }\end{array}$ & $17 \%$ & $10 \%$ & $24 \%$ & $4 \%$ & $3 \%$ & $25 \%$ & $17 \%$ \\
\hline & $\begin{array}{c}\text { Adjusted } \\
\text { residual }\end{array}$ & -4.8 & 40.2 & -18.9 & $-7.6 \%$ & 17.2 & -11.2 & 17.1 \\
\hline
\end{tabular}




\begin{tabular}{|c|c|c|c|c|c|c|c|c|}
\hline City & & Walking & Cycling & $\begin{array}{c}\text { Mass } \\
\text { public } \\
\text { transport }\end{array}$ & $\begin{array}{c}\text { Bus } \\
\text { public } \\
\text { transport }\end{array}$ & Train & $\begin{array}{c}\text { Car } \\
\text { transport }\end{array}$ & $\begin{array}{c}\text { Combined } \\
\text { transport }\end{array}$ \\
\hline Zlín & $\begin{array}{c}\text { Share of } \\
\text { transport }\end{array}$ & $15 \%$ & $1 \%$ & $35 \%$ & $4 \%$ & $2 \%$ & $31 \%$ & $12 \%$ \\
\cline { 2 - 9 } & $\begin{array}{c}\text { Adjusted } \\
\text { residual }\end{array}$ & -10.9 & -26 & 20.6 & -2.3 & -2.4 & 9.5 & -8.5 \\
\hline
\end{tabular}

(Source: The actual processing, 2018)

Table 7. Outbound travellers to work and school

(tabular scheme - adjusted residues)

\begin{tabular}{|c|c|c|c|c|c|c|c|}
\hline \multirow{2}{*}{ City } & \multicolumn{7}{|c|}{ Form of transport } \\
\cline { 2 - 7 } & Walking & Cycling & $\begin{array}{c}\text { Mass } \\
\text { public } \\
\text { transport }\end{array}$ & Bus & Train & $\begin{array}{c}\text { Car } \\
\text { transport }\end{array}$ & $\begin{array}{c}\text { Combined } \\
\text { transport }\end{array}$ \\
\hline $\begin{array}{c}\text { Olomouc } \\
\text { Liberec } \\
\text { České }\end{array}$ & +++ & -- & ++ & + & +++ & -- & - \\
Budějovice & +++ & -- & +++ & +++ & -- & +++ & -- \\
Hradec & ++ & +++ & -- & +++ & -- & -- & o \\
Králové \\
Ústín nad
\end{tabular}

(Source: The actual processing, 2018)

The data on the transport division of labour-adjusted residues and a sign chart for a set of inbound and outbound travellers to work and school are given in tables 8 and 9.

Table 8. Inbound and outbound travellers to work and school (transport division of labour and adjusted residues)

\begin{tabular}{|c|c|c|c|c|c|c|c|c|}
\hline \multirow{2}{*}{ City } & & Walking & Cycling & $\begin{array}{c}\text { Mass } \\
\text { public } \\
\text { transport }\end{array}$ & $\begin{array}{c}\text { Bus } \\
\text { public } \\
\text { transport }\end{array}$ & Train & $\begin{array}{c}\text { Car } \\
\text { transport }\end{array}$ & $\begin{array}{c}\text { Combined } \\
\text { transport }\end{array}$ \\
\hline Olomouc & $\begin{array}{c}\text { Share of } \\
\text { transport }\end{array}$ & $13 \%$ & $3 \%$ & $19 \%$ & $8 \%$ & $8 \%$ & $28 \%$ & $21 \%$ \\
\cline { 2 - 8 } & $\begin{array}{c}\text { Adjusted } \\
\text { residual }\end{array}$ & 17.6 & -10.3 & -3.1 & -5.6 & 26.8 & -26.8 & 13.4 \\
\hline \multirow{2}{*}{ Liberec } & $\begin{array}{c}\text { Share of } \\
\text { transport }\end{array}$ & $14 \%$ & $1 \%$ & $23 \%$ & $9 \%$ & $3 \%$ & $34 \%$ & $16 \%$ \\
\cline { 2 - 9 } & $\begin{array}{c}\text { Adjusted } \\
\text { residual }\end{array}$ & 18.8 & -31.4 & 24.1 & -1.8 & -25.2 & -9.6 & -19.7 \\
\hline
\end{tabular}


Division of labor in transport and the influence of the public sector

\begin{tabular}{|c|c|c|c|c|c|c|c|c|}
\hline City & & Walking & Cycling & \begin{tabular}{|c|} 
Mass \\
public \\
transport
\end{tabular} & $\begin{array}{c}\text { Bus } \\
\text { public } \\
\text { transport }\end{array}$ & Train & $\begin{array}{c}\text { Car } \\
\text { transport }\end{array}$ & $\begin{array}{l}\text { Combined } \\
\text { transport }\end{array}$ \\
\hline \multirow[t]{2}{*}{\begin{tabular}{|c|} 
České \\
Budějovice
\end{tabular}} & $\begin{array}{l}\text { Share of } \\
\text { transport }\end{array}$ & $10 \%$ & $4 \%$ & $17 \%$ & $12 \%$ & $4 \%$ & $34 \%$ & $19 \%$ \\
\hline & $\begin{array}{c}\text { Adjusted } \\
\text { residual }\end{array}$ & -7.8 & 17.8 & -13.7 & 23.8 & -21.1 & -9.1 & -3.6 \\
\hline \multirow[t]{2}{*}{$\begin{array}{l}\text { Hradec } \\
\text { Králové }\end{array}$} & $\begin{array}{l}\text { Share of } \\
\text { transport }\end{array}$ & $10 \%$ & $6 \%$ & $14 \%$ & $8 \%$ & $6 \%$ & $34 \%$ & $22 \%$ \\
\hline & \begin{tabular}{|c|} 
Adjusted \\
residual
\end{tabular} & -9 & 29.5 & -27.8 & -11.9 & 3.9 & 10.2 & 15.8 \\
\hline \multirow[t]{2}{*}{$\begin{array}{l}\text { Ústí nad } \\
\text { Labem }\end{array}$} & $\begin{array}{c}\text { Share of } \\
\text { transport }\end{array}$ & $10 \%$ & 0 & $24 \%$ & $4 \%$ & $9 \%$ & $33 \%$ & $19 \%$ \\
\hline & \begin{tabular}{|c|} 
Adjusted \\
residual
\end{tabular} & -7.2 & -31.3 & 26.5 & -31.2 & 28.4 & 0.8 & -1.8 \\
\hline \multirow[t]{2}{*}{ Pardubice } & $\begin{array}{c}\text { Share of } \\
\text { transport }\end{array}$ & $11 \%$ & $7 \%$ & $16 \%$ & $7 \%$ & $7 \%$ & $32 \%$ & $21 \%$ \\
\hline & \begin{tabular}{|c|} 
Adjusted \\
residual
\end{tabular} & -2.8 & 44.8 & -18.1 & -14.6 & 7.5 & -3.8 & 10.8 \\
\hline \multirow[t]{2}{*}{ Zlín } & $\begin{array}{c}\text { Share of } \\
\text { transport }\end{array}$ & $9 \%$ & $1 \%$ & $23 \%$ & $15 \%$ & $3 \%$ & $34 \%$ & $15 \%$ \\
\hline & \begin{tabular}{|c|} 
Adjusted \\
residual
\end{tabular} & -12.4 & -26.8 & 20.1 & 40 & -22.7 & 5 & -19.7 \\
\hline
\end{tabular}

(Source: The actual processing, 2018)

Table 9. Inbound and outbound travellers to work and school

(tabular scheme - adjusted residues)

\begin{tabular}{|c|c|c|c|c|c|c|c|}
\hline \multirow[b]{2}{*}{ City } & \multicolumn{7}{|c|}{ Form of transport } \\
\hline & Walking & Cycling & $\begin{array}{c}\text { Mass } \\
\text { public } \\
\text { transport }\end{array}$ & Bus & Train & $\begin{array}{c}\text { Car } \\
\text { transport }\end{array}$ & $\begin{array}{c}\text { Combined } \\
\text { transport }\end{array}$ \\
\hline Olomouc & +++ & -- & -- & -- & +++ & -- & +++ \\
\hline Liberec & +++ & -- & +++ & $\mathbf{0}$ & -- & +++ & -- \\
\hline České & -- & +++ & -- & +++ & -- & +++ & -- \\
\hline Dudejovice & & & & & & & \\
\hline Hradec Králové & -- & +++ & -- & -- & +++ & +++ & +++ \\
\hline Ústí nad Labem & -- & -- & +++ & -- & +++ & $\mathbf{0}$ & $\mathbf{o}$ \\
\hline Pardubice & -- & +++ & -- & -- & +++ & -- & +++ \\
\hline Zlín & -- & -- & +++ & +++ & -- & +++ & -- \\
\hline
\end{tabular}

(Source: The actual processing, 2018)

The adopted scenarios offer insight into transport division of labour from the perspective of the city inhabitants travelling to work and school and from the perspective of inbound and outbound travellers:

- Scenario outbound travellers 
- The share of walking, cycling and mass public transport is in the range from 48 to $55 \%$.

- The share of car transport represents $25-32 \%$.

- The share of the combined transport is $6-19 \%$.

- The share of bus and train 6-7\%.

- Scenario persons shuttling

- The share of walking, cycling and mass public transport is in the range from 30 to $38 \%$.

- The share of car transport represents $28-34 \%$.

- The share of the combined transport is $15-21 \%$.

- The share of bus and train $12-18 \%$.

The scenario of an outbound traveller is the default model for the transport division of labour and it shows the role of walking, cycling and mass public transport in urban mobility for local people travelling to work and school. The share of this group of means of transport on transport trips is 48 to $55 \%$.

The second scenario is a modification of the original distribution by factoring in the impact of the use of transport means by inbound travellers to the city from outside. The share of "urban public transport' falls to between 30 and 38 $\%$, the share of public transport and combined transport is growing significantly. The people who travel to work and school are relevant participants on urban mobility. The findings show that the development and changes in the urban transport system must consider the needs and circumstances of persons who are not residents, yet they significantly influence the urban mobility situation by their regular inbound travel.

The obtained results of the calculations allow us to accept several conclusions:

a) Generally applicable claims on the level, composition and changes in transport division of labour are represented by the sustained growth of car transport and the decline in the use of environmentally friendly modes of transport. This applies to all the examined cities. This also emerges from the comparison of the transport division of labour from the Census of population, apartments and houses from the years 2001 and 2011 (The census of population, apartments and houses, 2001) and (The census of population, apartments and houses, 2011).

b) The people living in the city, mainly work in the area and attend a local school. Their trips to work and school create the default transport division of labour model. This group of the population is the key in influencing the increase in use of environmentally friendly modes of transport.

c) The people regularly conducting inbound travel to work and school from other municipalities are causing a change in the default transport division of labour situation. The share of walking, cycling and mass public transport decreases and the importance of public and combined transport as well as car transport increases. 
d) The tested hypothesis of conformity of transport division of labour among regional capital has not been confirmed. It transpires that the structure of the use of the means of transport when travelling to work and school are different between the cities with statistical significance.

This finding means that the factors having a significant impact on the transport division of labour includes the tendency of the population to urban mobility within the city, the layout of the infrastructure for walking and cycling capacity and level of mass public transport.

Urban mobility of persons is important topic both for today and for the future. It is influenced by a number of changing synergistic and contradictory economic, social and ecological processes. The changes in residential and urban structure of cities, increase in separation of housing and workplaces, increasing preference of individual mobility, share of car transport on transport division of labour steadily increasing, mobility is attributed a high importance in the evaluation of quality of life, the quality of environmental is worsening.

The aim of this article was to verify that the distribution of the transport division of labour is or is not the same throughout the regional capitals in the Czech Republic. We base our research on a unique data set that was created in 2011 during the national population census. The employees and students also answered the question about the normal use of the means of transport for one journey to work or school.

In the analysis, we did not prove conformity to the same distribution of means of transport and subsequently we have quantified the statistically significant deviations in the use of the means of transport in the individual cities. For each one of the analysed cities, one or more of the means of transport are reported, where their share in the transport division of labour is inspiring for other cities in search of proposals to improve their transport division of labour composition.

The importance of transport division of labour must be seen in a wider context. The UN Summit on 25th September 2015 adopted the document "Transforming our World: The 2030 Agenda for Sustainable Development", which includes seventeen SDGs (Sustainable Development Goals, 2015). These included the subject of sustainable cities and municipalities. There is a requirement to "give all access to safe, affordable, easily accessible and sustainable transport systems, improve the safety of road traffic in particular by expanding public transport, with particular emphasis on the needs of people in a difficult situation as women, children, persons with disabilities and the elderly."

The plan of sustainable urban mobility (SUMP) represents the main tool for planning of urban mobility. (A methodology for the preparation of plans for sustainable mobility of cities in the Czech Republic, 2015). The methodology for its implementation comes from the applied research programme OMEGA "Integration planning for sustainability on urban level'. Work on the creation of SUMP consists of five phases (preparation, analysis, proposal, action plan implementation and evaluation). In the part which deals with the characteristics of mobility, transport division of labour (and its development) serves as the main 
indicator of mobility, in particular the share of car transport and strength and roles of its alternatives. The authors emphasize a great importance of the data source in the analytical stage of the plan. The main sources are calculated data from censuses of population, apartments and houses and other commonly monitored statistical data. The methodology emphasises the importance of the considered territory. The key for its determining should not be the administrative borders of local government districts, but the actual transport relations in the territory.

Other works involve the subject of modelling transport behaviour of urban populations and the emphasis is placed on restriction of car transport. The aim of the research project (Analysis of daily traffic behaviour of adult urban population and means of traffic regulation, 2008) was to ascertain why and how people commonly decide on use of different means of transport, including the identification of factors explaining the choice of the means of transport. The proposed model of behaviour is based on assumptions of rational choice, including attributes of alternatives such as travel time, travel expenses, characteristics of individuals (income, economic activity, gender, education, age, etc.). The authors connect greater use of car transport have with the type of population or type of housing and also with the distance of the residence from the city centre or workplace. Constraints in the use of car transport in urban mobility is linked with introduction of measures regulating transports, particularly economic ones.

The issue of city mobility is a frequent topic of investigation abroad. So, for example Basarić \& Jović (2011) proposed the target modal split model. The creators of the model examined the available databases of urban transport in European cities and through a correlation matrix analysis they chose 9 independent variables with the strongest impact on likelihood share of use of mass public transport and car transport in a transport trip. By repeating the regression analysis, they reached the final equation of modal split that serves allocation, which includes five variables: the number of buses per thousand inhabitants, price of parking per hour, monthly fare in mass public transport, density of public transport network, inbound travel into the city. The model has been successfully tested in the Serbian city of Novi Sad (250 000 inhabitants). The obtained results show that travel expenses are affecting the choice of means of transport.

In the article, we have been drawing attention to the importance of data sources on the use of the means of transport in urban mobility. In the analysis we used the data from the national Census of population, apartments and houses, 2011. However, this type of research is only conducted once per ten years and there are significant changes in the meantime. The SUMP methodology refers to the implementation of its own research, using a methodology of active travel surveys (Methodology of active travel surveys, 2014). In this case, the representative sample is limited to several hundred inhabitants. Regular industry-specific statistics represent an important source of information. For instance, data on the use of mass public transport are available. Data on transport operations of mass public transport in large cities are published annually in the annual reports (Association of transport companies in the Czech Republic, 2018). Data on personal car transport are 
published from the results of the national census of road transport, which, in the Czech Republic, is carried out every five-years (Road and Motorway Directorate of the Czech Republic, 2016).

\section{Conclusions}

The aim of this article was to verify whether the transport division of labor is or is or isn't consistent across regional capitals in the Czech Republic. After rejecting the conformity, the intention was to quantify the differences in the use of the means of transport in the city by determining the deviation of the observed values from the theoretical ones.

The conformity of the transport division of labor among the most important Czech cities has not been proven. Despite this, that the share of car transport on the total transport volume has been growing, in comparison to environmentally friendly modes of transport.

A detailed insight into the relationship between empirical and theoretical frequencies of use of the means of transport in cities shows mostly significantly more frequent deviations at the significance level of $0,1 \%$. Such findings reflect specific tendencies and habits of the populations of concrete cities regarding mobility, the impact of the scope and development level of infrastructure for walking, cycling and mass public transport.

In our investigation, we verified that the statistical methods used are a suitable analytical tool for such tasks as the assessment of the composition of the transport division of labor, when, for example, one city compares its level of modal split with the level of cities of a similar size. It may discover the strengths and weaknesses of the reported levels, investigate the causes of the reporting status, identify reasons strengths of similar cities, etc.

The transport division of labor is one of the main indicators of population mobility in a concrete territory. The shares of use of the different means of transport are the result of a gradual long-term development and are caused by number of factors. The main a lasting factor is represented by the continuous growth car ownership. This leads to the growth of the share of car transport on personal transport, cars being used for overcoming of increasingly shorter distances on one hand and declining walking, cycling and mass public transport on the other hand.

A systematic and systemic approach to the development of urban transport systems assumes the application of benchmarks credibly reflecting the planned and achieved progress, the potential impacts of the adopted measures, etc. In our case we have used a unique source of data from the Census of population, apartments and houses in 2011. However, such data is available only once per ten years. In further work on the transport division of labor we want to focus on the verification of the potential modelling of data on the use of mass public transport from regular industry-specific statistics and from research of national census of road transport. 
Also, we want to explore, how these sources could be used for comparison of different cities in terms of transport division of labor.

\section{References}

Bánociová, A., Martinková, S. (2017). Active Labour Market Policies of Selected European Countries and Their Competitiveness. Journal of Competitiveness, 9(3), pp. 5-21. DOI: 10.7441/joc.2017.03.01

Basaric', V. \& Jovic', J. (2011) Target modal split. Transport, 26(4), pp. 418-424. DOI: $10.3846 / 16484142.2011 .644044$

Becker U., Gerike R., \& Winter M. (2008). Základy dopravní ekologie. Praha: Ústav pro ekopolitiku.

Central Europe. Moderni cyklistika [on-line]. [2017-08-09] Retrived from https://www.cyklodoprava.cz/file/zivot-s-kolem-20-dobrych-duvodu-procyklistiku/

Centrum dopravního výzkumu. Metodika aktivně cestovních pri̊zkumů [on-line]. [2017-10-04] Retrived from http://www.cyklokonference.cz/cms_s oubory/rubriky/369.pdf

Centrum dopravního výzkumu. Metodika pro připravu plánů udržitelné mobility měst České republiky [on-line]. [2017-10-06] Retrived from https://www.cdv.cz/file/metodika-pro-pripravu-planu-udrzitelne-mobilitymest-ceske-republiky/

Český statistický úruad. Dojižd’ka do zaměstnání a škol [on-line]. [cit. 2017-09-03] Retrived from https://www.czso.cz/csu/czso/dojizdka-do-zamestnani-a-skolpodle-scitani-lidu-domu-a-bytu-2011-ceska-republika-2011-6elqhrcwol

Český statistický úřad. Sčitání lidu, bytů a domů 2001 [on-line]. [2017-09-03] Retrieved from https://www.czso.cz/csu/sldb/scitani_lidu_domu_a bytu_v_roce_2001

Český statistický úřad. Sčitání lidu, bytů a domů 2011 [on-line]. [2017-09-03] Retrieved from https://www.czso.cz/csu/sldb

Český statistický úřad. Statistická ročenka ČR [on-line]. [2017-09-03] Retrieved from https://www.czso.cz/csu/czso/statisticka-rocenka-ceske-republiky-2015

European Platform on Mobility Management. TEMS - The EPOMM Modal Split Tool [on-line]. [2018- 01-02] Retrieved from www.epomm.eu/tems

Kubík, J. (2016) Zlín Public Transport in Comparison with Cities of a Similar Size in the Czech Republic. Actual Problems of Economics, 17(10), pp. 218 227.

Magistrát města Hradec Králové Mobilita a mistni přeprava cestujicich, Město Hradec Králové [on-line]. [2017-12-05] Retrived from https://www.hradeckralove.org/urad/a3

Magistrát města Liberec. Plán udržitelné městské mobility Liberec - Jablonec nad Nisou [on-line]. [2017-12 -05] Retrived from http://www.chytrenacestu. cz/wp-content/uploads/2017/06/Zprava_pru\%CC\%8Azkumdopravni\%CC\%81ho-chova\%CC\%81ni\%CC\%811.pdf 
Magistrát města Zlína. Generel dopravy pro město Zlín [on-line]. [cit. 2017-11-10] Retrived from http://www.zlin.eu/clanky/dokumenty/6844/4369mkytpredstaveni-gdz-prezentace-v3.pdf

Magistrát města Jihlavy. Spokojenost občanů s místním společenstvím, mobilita a mistni preprava obyvatel Jihlavy [on-line]. [2017-12 -07] Retrieved from https://www.jihlava.cz/assets/File.ashx?id_org=5967\&id_dokumenty=50972 6

Ministerstvo dopravy ČR. Ročenky dopravy [on-line]. [2017-09-05] Retrieved from https://www.cdv.cz/rocenky-dopravy

Organizace spojených národů. Sustainable Development Goals [on-line]. [2018-0302] Retrieved from http://www.osn.cz/osn/hlavni-temata/sdgs/

Poliak, M., Poliaková, A., Mrníková, M., Šimurková, P., Jaśkiewicz, M., Jurecki, R. (2017). The Competitiveness of Public Transport. Journal of Competitiveness, 9(3). pp. 81-97. DOI: 10.7441/joc.2017.03.06

Pova, P. (2016) Dopravní obslužnost a socioekonomická úroveň regionů. Retrived from http://nf.vse.cz/workshop_admin/files/1256209334-5-8-930dc.pdf

Pucher, J. (2016) Urban Travel Behavior as the Outcome of Public Policy: The Example of Modal-Split in Western Europe and North America. Retrieved from http://www.tandfonline.com/doi/pdf/10.1080/01944368808976677? need Access=true. DOI: 10.1080/01944368808976677

Ředitelství silnic a dálnic ČR. Sčitání dopravy [on-line]. [2017-11-06] Retrieved from https://www.rsd.cz/wps/portal/web/Silnice-a-dalnice/Scitani-dopravy

Sdružení dopravních podniků ČR. Výroční správa [on-line]. [2018-02-02] Retrieved from www.sdp-cr.cz

Seidenglanz, D. (2007). Dopravni charakteristiky venkovského prostoru. Brno: Masarykova univerzita, Př́rodovědecká fakulta.

Schmeidler, K. (2010). Mobilita, transport a dostupnost ve městě. Ostrava: KEY Publishing.

Svoboda, P., Přidalová, I., \& Ouředníček, M. (2014). Historická geografie, 40(2), pp. 285-306.

Technologická platforma silniční dopravy. Studie Portfolio projektů pro strategickou výzkumnou agendu [on-line]. [2017-09-10] Retrieved from https://www.tpsd-ertrac.cz/file/portfolio-projektu-5-etapa-projektu-tpsd-1mobilita-a-osobni-silnicni-doprava/

Závěrečná zpráva z projektu MD 24/2006-430-OPI/3 z OP „Infrastruktura Priorita 2 (2,4)“. (2008) Analýza každodenniho dopravního chování dospělého městského obyvatelstva a nástroje regulace dopravy. Praha: Universita Karlova, Centrum pro otázky životního prostředí. 